\title{
Coarse-Grained Sentiment Analysis Berbasis Natural Language Processing - Ulasan Hotel
}

\section{(Coarse-Grained Sentiment Analysis Based on Natural Language Processing - Hotel Review)}

\author{
Warnia Nengsih ${ }^{1}$, M. Mahrus Zein ${ }^{2}$, Nazifa Hayati ${ }^{3}$
}

\begin{abstract}
Sentiment analysis is a method for obtaining data from various platforms available on the internet. Advances in technology enable the machine to recognize a term that is considered a positive opinion and vice versa. These data and opinions play an important role as product, services, or other topic feedback. Without the need to obtain an opinion directly from the public, the provider has obtained an important evaluation to develop themselves. Hospitality business is a field related to services, providing services to customers. Indicators of business continuity also depend on customer feedback and serve as a reference for strategic policy. Sentiment analysis techniques based on Natural Language Processing are expected to overcome these problems. In this study, the prediction uses a temporary Random Forest (RF) classifier to summarize the quality of the classifier then it can be done using the Receiver Operating Characteristic (ROC) curve. The ROC curve is a good graphic to summarize the quality of the classifier. The higher the curve is above the diagonal line, the better the prediction, with the ROC Curve value of 0.90 . The result shows that positive reviews are more than the negative reviews, i.e., $68 \%$ and $32 \%$, respectively.
\end{abstract}

Intisari-Sentiment analysis adalah metode untuk memperoleh data dari berbagai platform yang tersedia di internet. Kemajuan teknologi memungkinkan mesin untuk mengenali suatu istilah yang dianggap sebagai opini positif maupun sebaliknya. Datadata dan opini tersebut berperan penting sebagai umpan balik produk, layanan, dan topik lainnya. Tanpa perlu memperoleh opini secara langsung dari masyarakat, pihak penyedia telah mendapatkan evaluasi yang penting guna mengembangkan diri. Bisnis perhotelan merupakan bidang yang terkait dengan jasa memberikan layanan pada pelanggan. Indikator keberlangsungan bisnis ini juga bergantung pada umpan balik pelanggannya dan dijadikan sebagai acuan untuk pengambilan kebijakan strategis. Teknik sentiment analysis berbasis Natural Language Processing dapat mengatasi permasalahan tersebut. Pada makalah ini prediksi dilakukan menggunakan classifier Random Forest $(\boldsymbol{R F})$, sementara untuk merangkum kualitas classifier, digunakan kurva Receiver Operating Characteristic (ROC). Kurva ROC berupa grafik yang baik untuk merangkum kualitas classifier. Semakin tinggi kurva berada di atas garis diagonal, semakin baik prediksinya, dengan nilai kurva ROC yang diperoleh sebesar 0,90 . Terlihat hasil ulasan terhadap opini pelanggan terhadap jasa dan pelayanan yang diberikan oleh hotel untuk kategori positif lebih banyak daripada kategori negatif.

1,2,3 Jurusan Teknik Informatika, Politeknik Caltex Riau, Jl. Umbansari No Rumbai Pekanbaru Riau 28265 (tlp: 0761-53939; fax:0761-554224; e-mail: ${ }^{1}$ warnia@ @cr.ac.id, ${ }^{2}$ mahrus@ @cr.ac.id)
Polaritas dari ulasan diperoleh $68 \%$ ulasan pelanggan berada pada area positif dan $32 \%$ berada pada area negatif.

Kata Kunci-Coarse Grained, Sentiment Analysis, NLP, Hotel.

\section{PENDAhUluan}

Sentiment analysis merupakan bagian dari Natural Language Processing (NLP). Teknik ini sangat baik untuk menentukan hasil ulasan (review) dari sebuah opini pengguna (user). Sentiment analysis adalah salah satu teknik ekstraksi dari sebuah informasi terhadap sebuah isu dan kejadian. Teknik ini digunakan untuk menemukan opini dan paparan terhadap suatu isu atau kejadian dalam bentuk teks. Sentimen merupakan pernyataan subjektif yang mencerminkan persepsi seseorang terhadap suatu peristiwa [1]. Ekstraksi dari opini masyarakat mengenai produk atau layanan dari hampir semua bidang. Secara umum, sentiment analysis terbagi menjadi dua kategori besar, yaitu:

- coarse-grained sentiment analysis,

- fined-grained sentiment analysis.

Coarse-grained sentiment analysis melakukan proses analisis pada level dokumen. Pengklasifikasian berorientasi pada sebuah dokumen secara keseluruhan, yaitu positif, netral, dan negatif. Sementara itu, fined-grained sentiment analysis melakukan proses analisis sebuah kalimat [2].

Tujuan makalah ini adalah menghasilkan sentiment analysis pada ulasan pelanggan hotel sehingga pola yang diperoleh dapat dijadikan sebagai acuan dalam pengambilan kebijakan berikutnya, agar dapat membantu meningkatkan kualitas pelayanan dengan nilai akurasi yang lebih baik. Ulasan produk yang dibuat oleh pengguna online dapat berdampak terhadap keputusan membeli pelanggan lain [3]. Ulasan dapat membantu pelanggan dalam membentuk kriteria untuk mengevaluasi produk dan mengurangi biaya kognitif dalam membuat keputusan pembelian [4]. Ulasan produk online juga dapat membantu pelanggan untuk: (1) membentuk pemahaman tentang suatu produk; (2) membangun kriteria untuk mengevaluasi produk; (3) membantu membuat keputusan yang tepat; dan (4) mengurangi biaya kognitif dalam membuat keputusan.

Berikut merupakan ulasan penelitian terdahulu terkait dengan makalah ini. Beberapa penelitian menggunakan metode Naive bayes dan rapid miner serta data miner sebagai tools pengolahannya. Pengujian validitas data menggunakan 10-fold cross validation dengan rata-rata nilai akurasi sebesar $89 \%$. Sumber dataset yang digunakan diperoleh dari Hotels.com, 


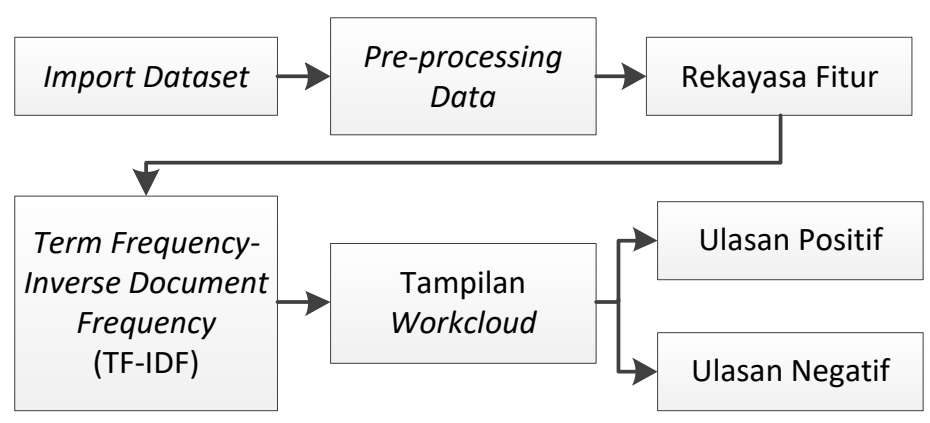

Gbr. 1 Alur perancangan coarse grained sentiment analysis.

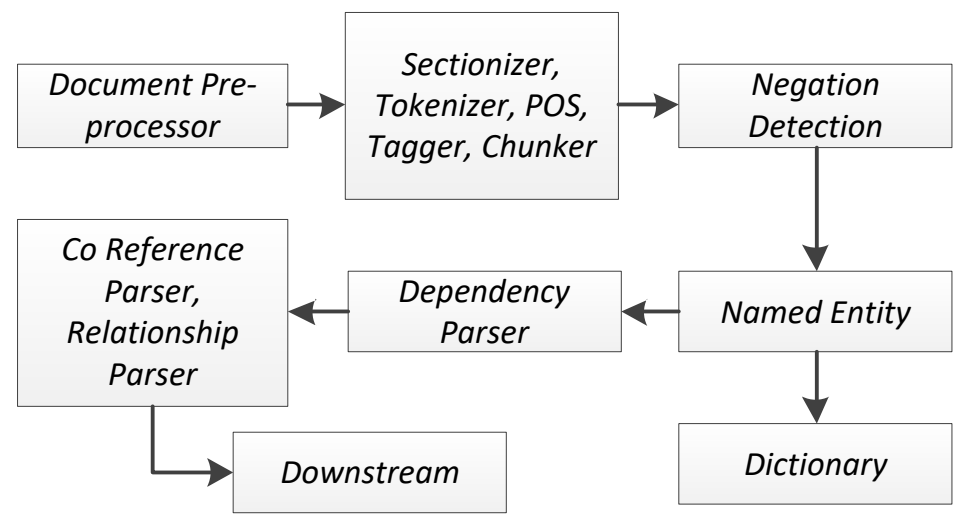

Gbr. 2 Mekanisme Natural Langunge Processing (NLP).

booking.com, dan agoda.com serta menggunakan Python untuk pengolahannya. Dataset yang digunakan bersumber dari dataset hotel_reviews.csv, berbasis coarse-grained sentiment analysis berbasis NLP. Sementara itu, untuk menghitung kinerja algoritme klasifikasi yang ditampilkan dalam bentuk grafik, digunakan kurva Receiver Operating Characteristic $(R O C)$ [4]-[6].

Bisnis perhotelan merupakan bidang yang erat kaitannya dengan kepuasan pelanggan. Kepuasan pelanggan menjadi tolok ukur keberhasilan dari rumusan capaian yang diperoleh pada sebuah bisnis. Indikator keberlangsungan bisnis ini juga bergantung pada respons pelanggannya dan dijadikan sebagai acuan untuk pengambilan kebijakan strategis. Permasalahan yang terjadi adalah level manajemen tidak mengetahui dan belum menemukan pola dari respons pelanggan hotel terkait layanan produk dan jasa yang diberikan. Penerapan teknik sentiment analysis berbasis NLP diharapkan dapat mengatasi permasalahan yang berhubungan dengan umpan balik pelanggan terhadap layanan produk atau jasa yang diberikan. Aktivitas untuk merangkum kualitas classifier dilakukan menggunakan kurva ROC. Kurva ROC berupa grafik yang baik untuk merangkum kualitas classifier. Semakin tinggi kurva berada di atas garis diagonal, semakin baik hasil prediksi [7][10].

\section{Metodologi}

Dataset yang digunakan adalah dataset hotel_reviews.csv. Dataset ini merupakan kumpulan ulasan pelanggan dari salah satu situs perjalanan terkemuka. Pada dataset ini terdapat 51.574 baris dan 3.840 atribut data [11]. Dataset ini berisi komentar pelanggan terhadap layanan yang terdapat pada sebuah hotel. Tentunya komentar dan hasil ulasan memengaruhi keputusan pelanggan untuk melakukan order terhadap produk yang ditawarkan, sehingga manajemen hotel harus dapat melakukan ekstraksi dan menggali informasi kecenderungan komentar atau ulasan tersebut berada dalam kelompok atau kategori tetentu. Dengan hasil tersebut, diperlukan sebuah knowledge untuk dijadikan sebagai acuan terkait dengan pengambilan keputusan strategis di masa depan. Jenis sentiment analysis yang digunakan adalah coarse grained sentiment analysis, yang merupakan jenis sentiment analysis yang dilakukan pada level dokumen, dengan seluruh isi dokumen dianggap sebagai sebuah sentimen positif dan negatif. Isi dokumen pada dataset ini diperoleh dari beberapa variabel yang digunakan, di antaranya ulasan deskripsi dari setiap pelanggan, browser, serta device yang digunakan.

\section{PERANCANGAN}

Berikut merupakan alur perancangan coarse grained sentiment analysis. Dataset yang akan diolah bersumber dari hotel_reviews.csv, yang selanjutnya dikenai data preprocessing, term frequency-inverse document frequency, untuk menentukan kategori ulasan positif dan ulasan negatif yang dihasilkan.

Gbr. 1 memberikan gambaran tentang alur perancangan coarse grained sentiment analysis. Dataset yang digunakan harus melalui tahapan data pre-processing. Bagian ini dikenal dengan tahapan text pre-processing. Proses pre-processing ini meliputi: (1) case folding, (2) tokenizing, (3) filtering, dan (4) 
Out [1]:

Gbr. 3 Keluaran pengelompokan kategori.

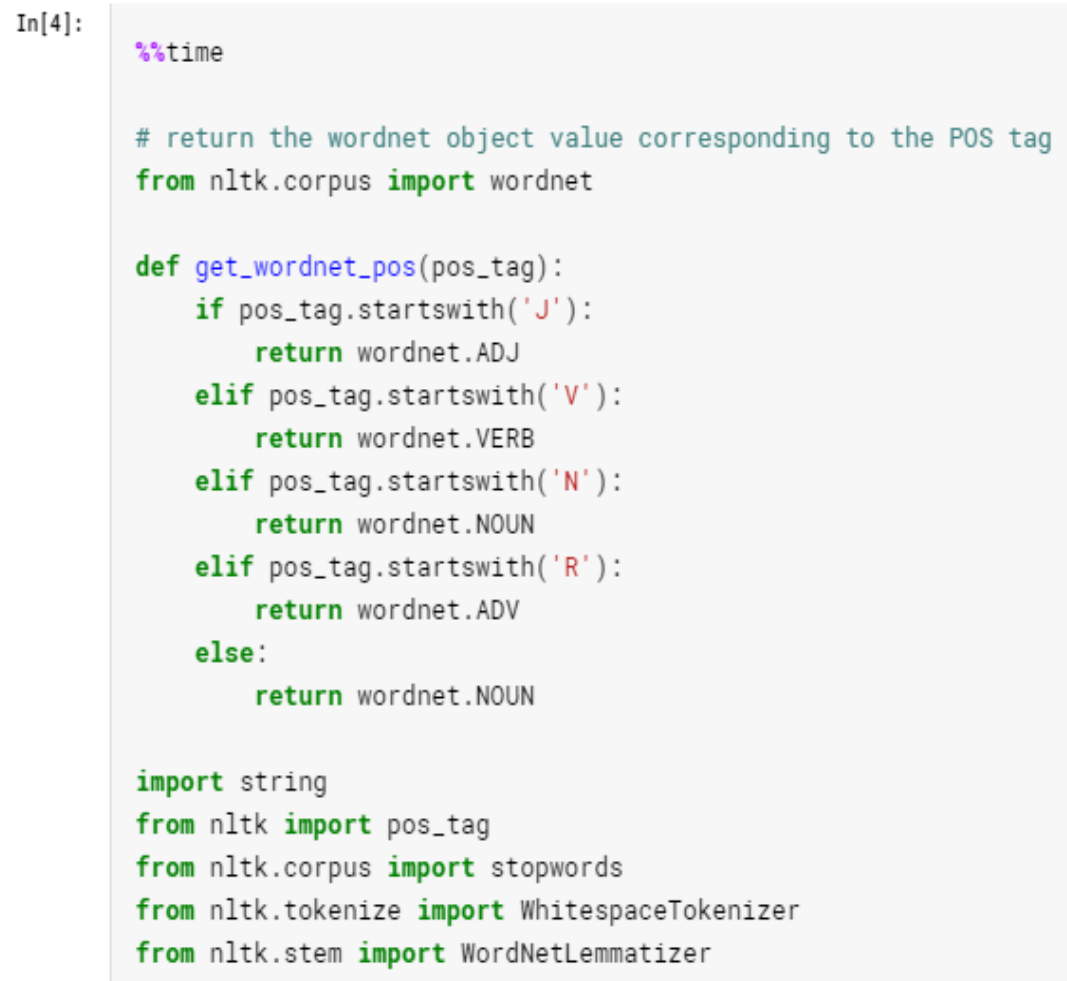

Gbr. 4 Data pre-processing.

stemming. Tahap akhir dari text pre-processing adalah termweighting. Term-weighting merupakan proses pemberian bobot term pada dokumen. Pembobotan ini digunakan untuk klasifikasi dokumen menggunakan Term Frequency-Inverse Document Frequency (TF-IDF).

Gbr. 2 menjelaskan tentang mekanisme NLP. Mekanisme ini dimulai dari tahapan document pre-processor, sectionizer, tokenizer, POS tagger, chunker, sampai pada tahapan downstream application.

\section{IV.PEMBAHASAN}

Dari deskripsi ulasan yang terdapat pada dataset yang digunakan, terlebih dahulu perlu dilakukan pengelompokan kategori. Pandas berguna dalam memasukkan file data ke dalam
Python.reviews_df["review"]=reviews_df["Negative_Review"]+re views_df["Positive_Review"]

yang berfungsi untuk membagi setiap ulasan tekstual, yaitu dibagi menjadi bagian positif dan negatif dan mengelompokkannya.

Gbr. 3 memperlihatkan keluaran yang dihasilkan dalam pengelompokan kategori positif dan negatif. Pada gambar tersebut terlihat hasil pengelompokan setiap ulasan dari komentar yang ada. Ulasan positif diinisialisasi dengan nilai 1 dan ulasan negative diinisialisasi dengan nilai 0 .

Proses pembersihan data dilakukan dengan melakukan: import wordnet, import String, import pos_tag, import stopword, import WhitespaceTokenizer, dan import WordNetLemmatizer. Pos_tag adalah simbol yang mewakili 


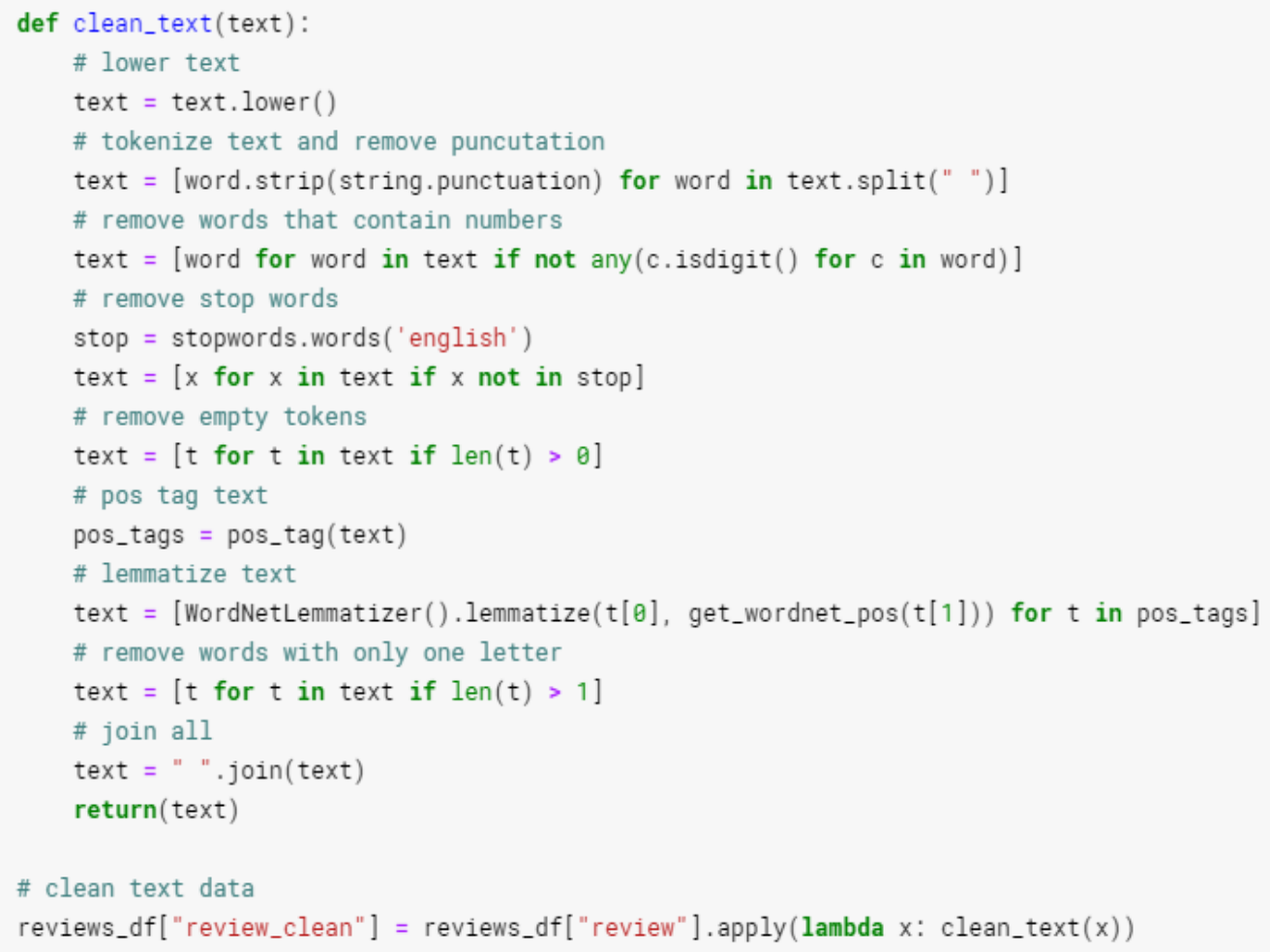

Gbr. 5 Proses pembersihan data tekstual.

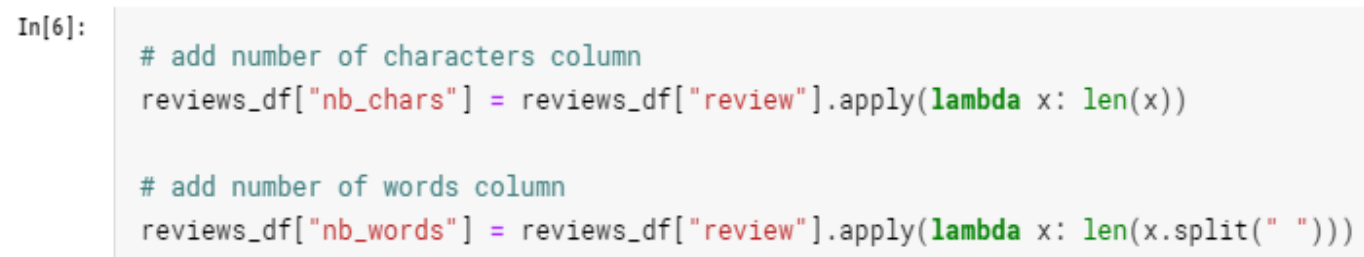

Gbr. 6 Penambahan karakter dan teks.

kategori leksikal: NN (noun), VB (verb), JJ (adjective), dan AT (article).

Gbr. 4 merupakan proses untuk tahapan data pre-processing. Ada beberapa tahapan yang dilakukan, mulai dari tahapan pengelompokan kata sampai ke proses tokenizer.

Gbr. 5 menjelaskan tentang pembersihan data tekstual menggunakan fungsi 'clean text' dan dilakukan beberapa transformasi, seperti lower text (membuat huruf menjadi kecil); tokenize the text (memisahkan teks menjadi kata-kata); menghapus tanda baca; menghapus kata-kata yang berisi angka; menghapus kata-kata stop word, seperti 'the', 'a', dan 'this'; menghapus tanda yang kosong; menandai Part-of-Speech (POS): menetapkan tag untuk setiap kata untuk didefinisikan jika sesuai dengan kata benda, kata kerja; serta lemmatize teks (mengubah setiap kata menjadi bentuk dasarnya).
Tahap selanjutnya adalah rekayasa fitur, dimulai dengan menambahkan fitur sentiment analysis. Proses ini menggunakan Vader, yang merupakan bagian dari modul NLTK yang dirancang untuk sentiment analysis. Vader menggunakan kamus kata untuk menemukan kata-kata yang masuk ke dalam kategori positif atau negatif.

Gbr. 6 menjelaskan penambahan beberapa metrik sederhana untuk setiap teks. Penambahan teks ini dapat berupa penambahan kolom untuk jumlah karakter dalam teks dan penambahan kolom untuk jumlah kata dalam teks.

Pada Gbr. 7 diperlihatkan modul Gensim membuat representasi vektor numerik dari setiap kata dalam korpus dengan menggunakan konteks Word2Vec. Selanjutnya, ditambahkan nilai TF-IDF untuk setiap kata dan setiap dokumen, dengan term frequency menghitung jumlah 


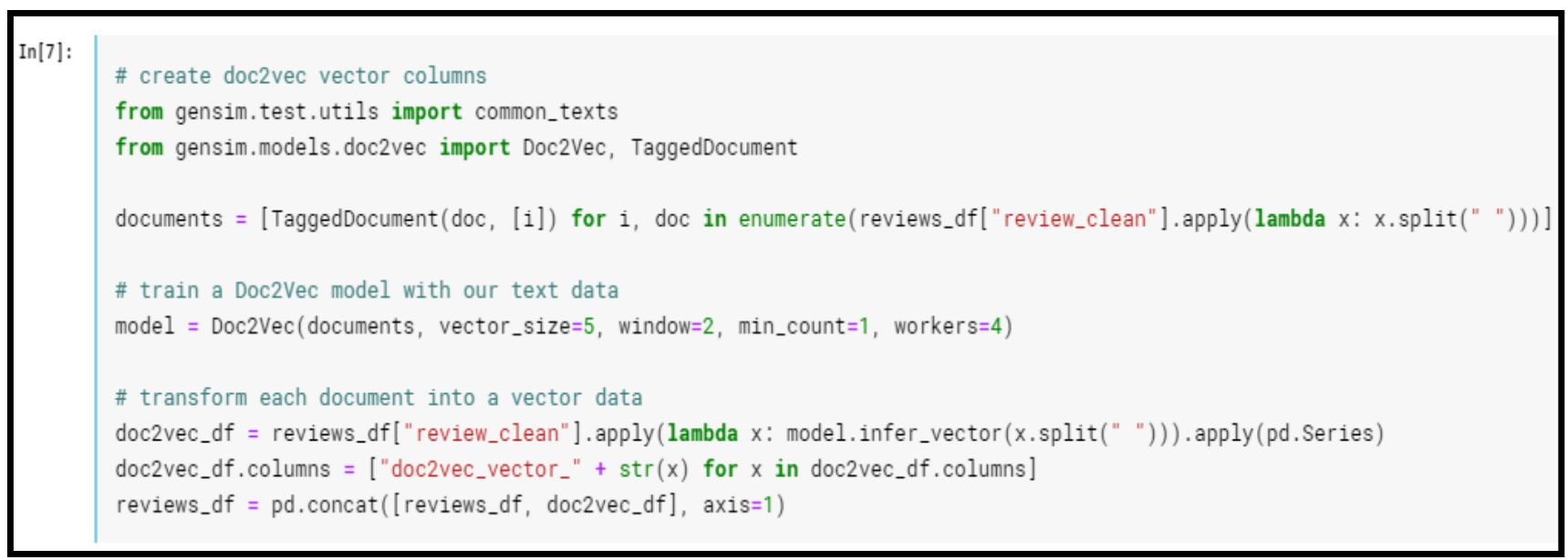

Gbr. 7 Representasi vektor numerik.

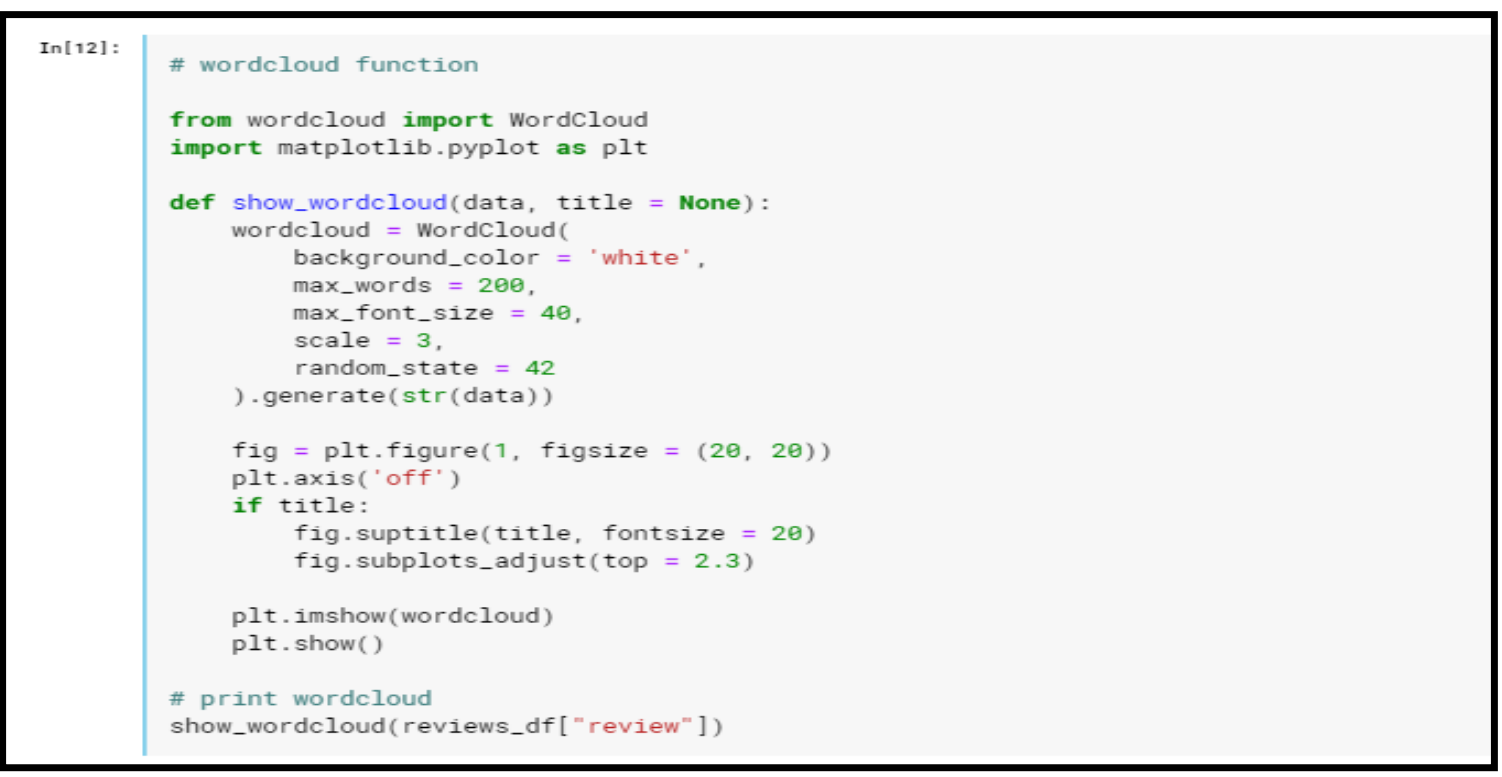

Gbr. 8 Fungsi wordcloud.

kemunculan kata klasik dalam teks, sementara inverse document frequency menghitung kepentingan relatif dari kata, yang tergantung pada banyak teks kata dapat ditemukan.

Untuk menampilkan jumlah ulasan negatif, menggunakan reviews_df, Hasil dari reviews $d f$ menunjukkan hasil untuk nilai negatif dan nilai positif dengan persentase $95 \%$ untuk nilai positif dan $0,43 \%$ untuk komentar negatif.

Gbr. 8 menunjukkan tahapan untuk menampilkan wordcloud. Tampilan wordcloud digunakan untuk melihat sekilas kata-kata yang muncul di ulasan. Wordcloud adalah teknik visualisasi data yang digunakan untuk mewakili data teks dengan ukuran setiap kata menunjukkan frekuensi. Pada tampilan ini terdapat kata dengan frekuensi kemunculan yang berulang, di antaranya: "staff", "excellent", "nothing", "hotel", "friendly", dan "breakfast".

Gbr. 9 merupakan hasil dari fungsi wordcloud yang sudah dilakukan. Terdapat beberapa kata yang mewakili kemunculan kata. Ulasan positif tertinggi lebih dari lima kata untuk sepuluh data, seperti ditunjukkan pada Gbr. 10. Ada beberapa kata positif yang terdeteksi, seperti: "perfect","clean", “lovely staff", "great place","beautiful", dan "good value".

Gbr. 11 menampilkan ulasan negatif tertinggi lebih dari lima kata untuk sepuluh data. Ada beberapa kata negatif yang terdeteksi, seperti: “dislikes", "noisy", "very bad", dan "nothing great".

Gbr. 12 menunjukkan visualisasi yang dihasilkan, dengan warna biru pada grafik menunjukkan ulasan positif dan warna oranye menunjukkan ulasan negatif. Pada grafik tersebut terlihat hasil ulasan terhadap opini pelanggan untuk kategori positif lebih banyak daripada kategori negatif.

Pada good reviews terlihat bahwa statistik yang ditampilkan naik turun, sementara bad reviews masih berada pada ulasan atau komentar negatif dalam kondisi yang normal.

Selanjutnya adalah memilih fitur yang akan digunakan pada data training lalu mengelompokkannya menjadi data training dan testing. Untuk melakukan prediksi, digunakan classifier Random Forest (RF). 


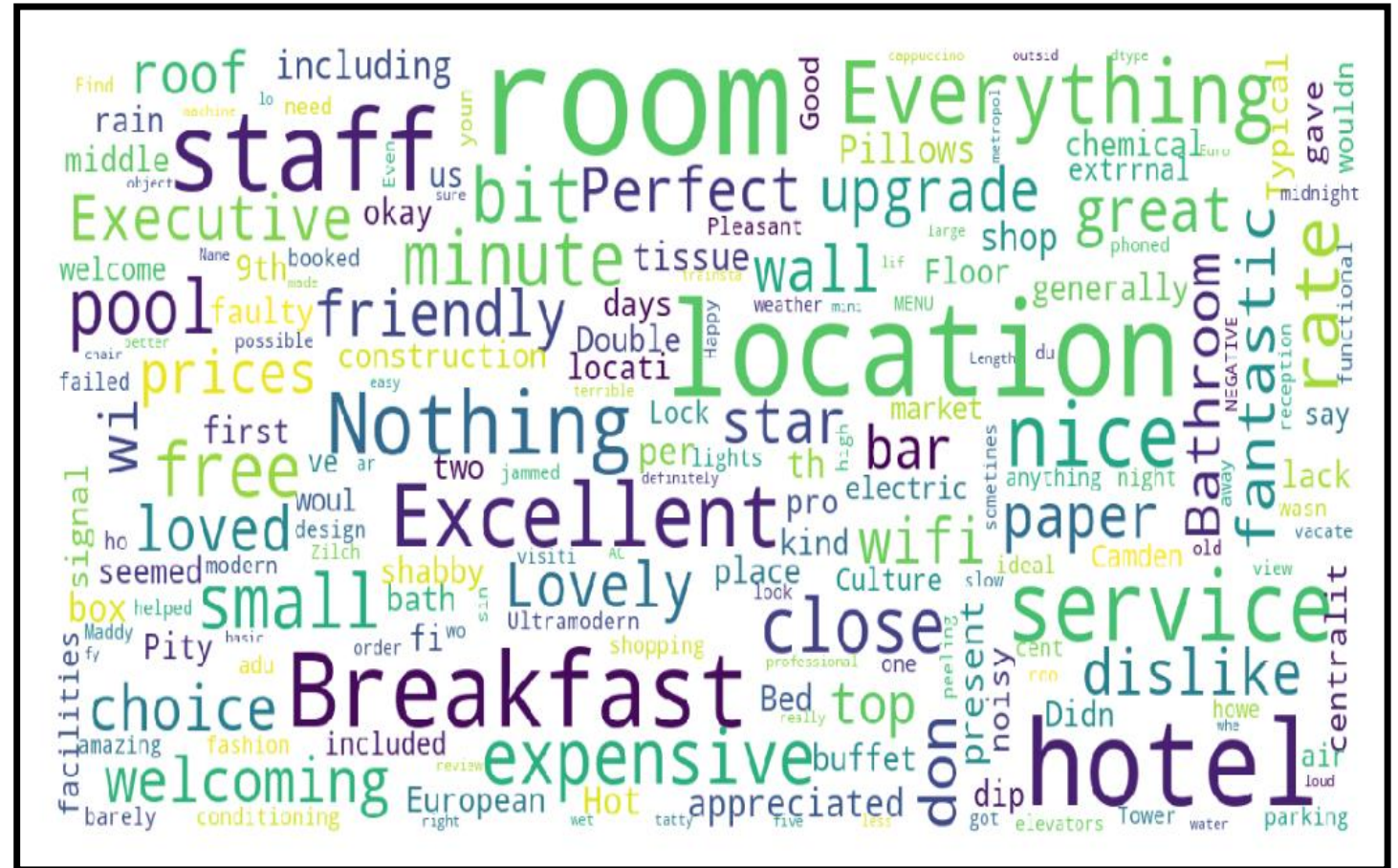

Gbr. 9 Hasil wordcloud function.

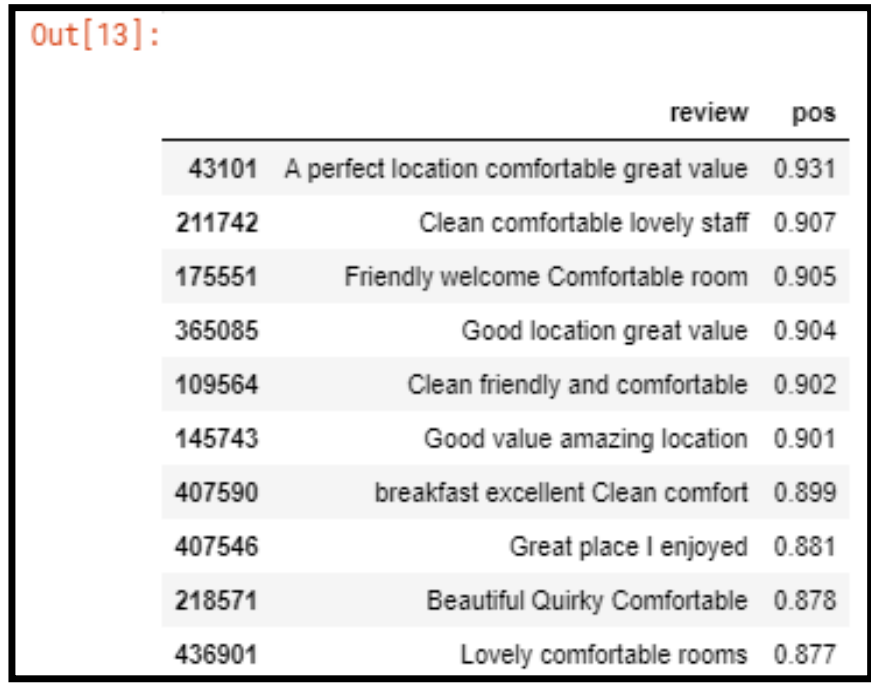

Gbr. 10 Ulasan positif.

Gbr. 13 menunjukkan pengelompokan pada data training secara acak untuk melakukan prediksi dengan nilai estimasi sebesar 100 dan random states 42, dengan fitur yang ditampilkan hanya dua puluh record saja.

Untuk merangkum kualitas classifier digunakan kurva ROC. Kurva ROC merupakan representasi grafis untuk menggambarkan keakuratan diagnostik. Kurva berada di atas garis diagonal. Semakin tinggi kurva berada di atas garis diagonal, semakin baik nilai prediksi yang dihasilkan. Diperoleh nilai kurva ROC sebesar 0,90. Polaritas dari ulasan yang diperoleh yaitu $68 \%$ ulasan pelanggan berada pada area positif dan $32 \%$ berada pada area negatif, dengan nilai akurasi prediksi $90 \%$.

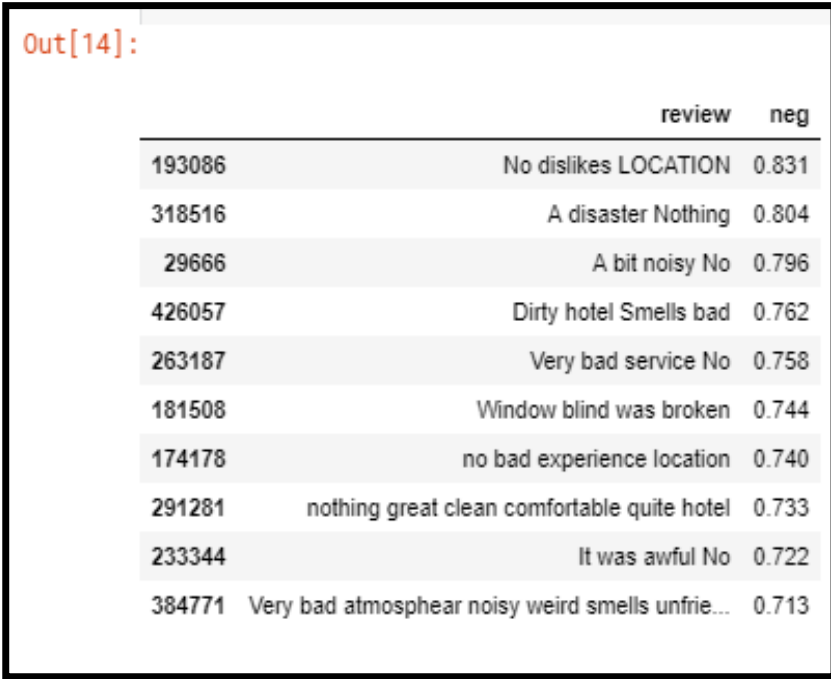

Gbr. 11 Ulasan negatif.

\section{KESIMPULAN}

Sentiment analysis pada ulasan pelanggan hotel menghasilkan klasifikasi ulasan untuk kategori positif dan negatif dari komentar yang diberikan pelanggan. Pola yang diperoleh dapat dijadikan sebagai acuan dalam pengambilan kebijakan bagi level manajemen. Rangkuman kualitas classifier pada makalah ini menggunakan kurva ROC dengan nilai sebesar 0,90. Semakin tinggi kurva berada di atas garis diagonal, semakin baik prediksi. Polaritas dari ulasan yang diperoleh adalah $68 \%$ ulasan pelanggan berada pada area positif dan $32 \%$ berada pada area negatif, dengan nilai akurasi prediksi sebesar $90 \%$. 


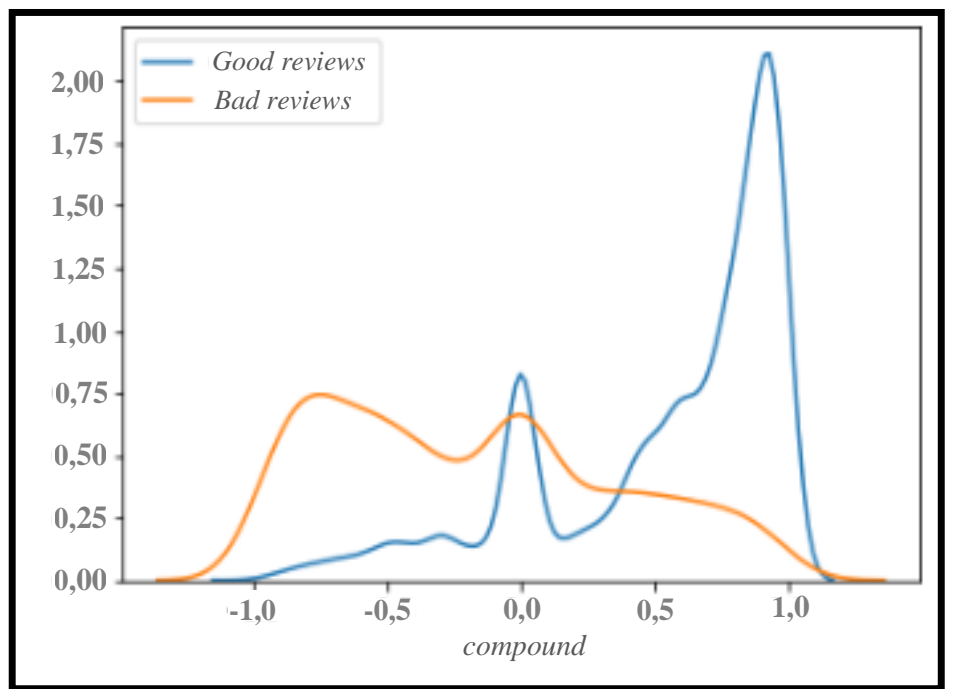

Gbr. 12 Ulasan warna positif dan negatif.

\begin{tabular}{|c|c|c|c|}
\hline \multicolumn{4}{|l|}{ Out [17]: } \\
\hline & 3 & compound & 0.038355 \\
\hline & 2 & pos & 0.024718 \\
\hline & 0 & neg & 0.023400 \\
\hline & 8 & doc2vec_vector_2 & 0.020461 \\
\hline & 6 & doc2vec_vector_0 & 0.019230 \\
\hline & 7 & doc2vec_vector_1 & 0.017899 \\
\hline & 9 & doc2vec_vector_3 & 0.016996 \\
\hline & 10 & doc2vec_vector_4 & 0.016483 \\
\hline & 4 & nb_chars & 0.016391 \\
\hline & 1 & neu & 0.014577 \\
\hline & 5 & nb_words & 0.013880 \\
\hline & 2239 & word_nothing & 0.009913 \\
\hline & 2853 & word_room & 0.009530 \\
\hline & 950 & word_dirty & 0.009411 \\
\hline & 285 & word_bad & 0.008820 \\
\hline & 3202 & word_staff & 0.006799 \\
\hline & 1945 & word_location & 0.006683 \\
\hline & 1639 & word_hotel & 0.006280 \\
\hline & 3216 & word_star & 0.006267 \\
\hline & 2867 & word_rude & 0.005898 \\
\hline
\end{tabular}

Gbr. 13 Pengelompokan pada data training secara acak.

\section{REFERENSI}

[1] K. Zvarevashe dan O. O. Olugbara, "A Framework for Sentiment Analysis with Opinion Mining of Hotel Reviews," Proc. Conf. Inf. Commun. Technol. Soc. (ICTAS), 2018, hal. 1-4.

[2] G. Walsh, K.P. Gwinner, dan S.R. Swanson, "What Makes Mavens Tick? Exploring the Motives of Market Mavens' Initiation of Information Diffusion, Journal of Consumer Marketing, Vol. 21, No. 2, hal. 109-122, 2014.
[3] Y. Liu, P. Li, dan S. Liu, "Opinion Mining and Sentiment Analysis," Zhonghua Bing Li Xue Za Zhi, Vol. 24, No. 2, hal. 72-74. 1995.

[4] T. Ghorpade dan L. Ragha, "Featured Based Sentiment Classification for Hotel Reviews Using NLP and Bayesian Classification," Proc. Int. Conf. Commun. Inf. Comput. Technol. (ICCICT), 2012, hal. 1-5.

[5] V.B. Raut dan D.D. Londhe, "Opinion Mining and Summarization of Hotel Reviews," Proc. - 2014 6th Int. Conf. Comput. Intell. Commun. Networks, (CICN), 2014, hal. 556- 559. 
[6] P. Prameswari, I. Surjandari, dan E. Laoh, "Opinion Mining from Online Reviews in Bali Tourist Area," Proc. 3rd Int. Conf. Sci. Inf. Technol. (ICSITech), 2017, hal. 226-230.

[7] P. Juneja dan U. Ojha, "Casting Online Votes: To Predict Offline Results Using Sentiment Analysis by Machine Learning Classifiers," 8th Int. Conf. Comput. Commun. Netw. Technol. (ICCCNT2017), 2017, hal. 1-6.

[8] M. Abbas, K.A. Memon, A.A. Jamali, S. Memon, dan A. Ahmed, "Multinomial Naive Bayes Classification Model for Sentiment Analysis," Int. Journal of Computer Science and Network Security (IJCSNS), Vol. 19, No. 3, 2019, hal. 62-67.
[9] S. George dan S. Joseph, "Text Classification by Augmenting Bag of Words (BOW) Representation with Text Classification by Augmenting Bag of Words (BOW) Representation with Co-occurrence Feature", IOSR Journal of Computer Engineering, Vol. 16, No. 1, hal. 34-38, 2014.

[10] E. Indrayuni, "Analisa Sentimen Review Hotel Menggunakan Algoritma Support Vector Machine Berbasis Particle Swam Optimization," $J$. Evolusi, Vol. 4, No. 2, hal. 20-27, 2016.

[11] (2019) "Hotel Reviews", [Online], https://www.kaggle.com/datafiniti/hotelreviews, tanggal akses: 1-Sep2019. 